\title{
Arthur Ransome and Dmitri Mitrokhin: Translating the Russian Folktale
}

\author{
Tatiana Bogrdanova \\ University of Eastern Finland (Joensuu) \\ Correspondence concerning this article should be addressed to Tatiana Bogrdanova, University of Eastern \\ Finland (Joensuu) Yliopistokatu 2, Joensuu, Finland, FI-80100. E-mail: tatianb@uef.fi
}

\begin{abstract}
Asya Usmanova
Moscow State University

Correspondence concerning this article should be addressed to Asya Usmanova, Faculty of Foreign Languages and Area Studies Lomonosov Moscow State University, Lomonosov Str., 31, Bldg. a, Moscow, Russian Federation, 119192.E-mail: asiya-9191@mail.ru
\end{abstract}

\begin{abstract}
This paper focuses on Arthur Ransome's and Dmitri Mitrokhin's collaboration in translating the Russian folktales. Old Peter's Russian Tales (1916), Ransome's first serious (and sustained) success, was the translation product of his early sojourns in Russia, illustrated by Dmitri Mitrokhin. The aims of the research are threefold: (1) to explore the cooperation between the British translator and the Russian artist in translating Russian folktales as an insight into the intense British-Russian dialogues of the time; (2) to examine the interaction of the translated texts and the images in terms of the translation strategy employed, as well as the influences of the contemporaneous tastes and trends; (3) to gain a better understanding of the translator's agency and human interaction in building an important link between the cultures and the countries. The research has required close reading of primary and secondary sources, including archival materials, as well as the textual analysis of the translated stories, the translator's correspondence and other papers pertaining to his micro-history. These latter are used to explore the interplay of the translated text and the pictures against the background of personal, as well as wider British-Russian cultural interaction at the turn of the twentieth century. Ransome's book of over three hundred pages was illustrated with Mitrokhin's seven full-page coloured pictures and twenty nine black and white head-pieces and end-pieces, which the author found admirable and his publishers were pleased with, though later editions would be illustrated by the other artists as well. Ransome's translation strategy in retelling the Russian tales to his young reader at home was largely domesticating; however, he was careful to convey their culturally specific character, which was enhanced by Mitrokhin's effort to acquaint the foreign reader with the Russian peasant world. The main result achieved is that the examination of the interplay between the text and the picture shows the specific relevance of aesthetically and emotionally powerful images in rendering the culturally distinct character of folktales. This is, therefore, a case study of the intercultural dialogue between the translator and the artist which produced an interesting interpretation of Russian folklore for the international reader and made an important contribution to the cultural links between the countries.
\end{abstract}

Keywords: translation history, Old Peter's Russian Tales, Arthur Ransome, Dmitri Mitrokhin, cultural interaction, affinity, British-Russian enchantment at the turn of the twentieth century

With the ubiquity of the translation activity in the modern world followed by the present 'boom' in translation studies, there is a growing understanding that translation is an integral part of cultural interaction and mediation, and translators are increasingly appreciated as influential agents of that process in the past and present. Importantly, Anthony Pym argues that to make "narrative sense of relations between cultures", translation history should focus on portraying "active people in the picture and some kind of human interaction at work" (2009, pp. 23-24). This calls for a detailed examination of the agency of translators, that is, their willingness and ability to act, embedded in their surrounding practices and professional environments (Kinnunen \& Koskinen, 2010, pp. 6-8).

This is the general conceptual and methodological framework of the present paper, which focuses on the 
agency of a translator of Russian folklore in the early twentieth century, as well as on the intercultural contexts in which he worked. Hence, a close reading of primary and secondary sources has been undertaken to reconstruct the general atmosphere of the time. The case study of the British translator's cooperation with the Russian artist in translating the Russian folktale for international audiences gives a deeper insight into the human interaction in the contemporaneous literary and artistic field. Also, by exploring the translated texts in terms of the translation strategy and techniques employed, the paper draws the reader's attention to the interplay between text and image. Illustrations, an important visual presence in translation products, are, unfortunately, often overlooked: they may in fact domesticate or foreignize a story by bringing it closer to or further away from the target culture (Oittinen, 2005, p. 55), as well as realize a number of functions in the texts including: (i) interacting with the text and its message; (ii) alluding to other texts or images; (iii) reflecting current artistic norms, trends, and tastes; (iv) informing about the cultural context; (v) adding to the emotional dimension of the text (Fischer, 2008, p. 99).

The cultural environment at the turn of the twentieth century can be characterized by mutual interest and a search for understanding between Britain and Russia, especially as far as the intellectual circles were concerned. It was conducive to the success of Ransome and Mitrokhin's undertaking, despite obvious difficulties, that the folklore material presents both in terms of translation and reception by target audiences (Timoczko, 1995; TerMinasova, 2000). Ransome took great pains to render the attractiveness of the new magic world he had discovered by rewriting Russian folktales in accordance with the British tradition of fairy tales whose avid readership he counted himself among. Mitrokhin's illustrations were, in fact, the final touches in this ingenious appeal to the young British reader, notably, imparting something of the brilliance and beauty of the epoch to the book.

\section{Materials and Methods}

\section{Research: Aims, Data, and Methods}

The aims of the research are, firstly, to explore the cooperation between the British translator and the Russian artist in translating Russian folktales as an insight into the intense British-Russian dialogues of the time; secondly, to examine the interaction of the translated texts and the images in terms of the translation strategy employed, as well as the influences of the contemporaneous tastes and trends; finally, to gain a better understanding of the translator's agency and human interaction in building an important link between the cultures and the countries.

The translator in question is Arthur Ransome (18841967), most famous for his Swallows and Amazons (1930-
47) series of children's holiday adventure novels, which he wrote in his forties after settling down in the Lake District. Prior to becoming a children's literature classic, he spent apprenticeship years in London and then in journalistic service as a correspondent for the Daily News and the Manchester Guardian in Russia, the Middle East and China (Ransome, 1976; Brogan, 1984).

The primary source of data analyzed is Old Peter's Russian Tales (1916), the translation product of his early sojourns in Russia and Ransome' $s$ first serious (and sustained) success. It is three hundred and thirtyfour pages long, and is rather sparingly but nevertheless effectively illustrated with seven coloured full-page pictures, twenty black and white head-pieces, and nine black and white end-pieces by Mitrokhin. This book, which has today attained status as a classic, was also the concluding chapter of the first period in the literary career of the young author who left England for Russia to pursue a passion for folklore, as well as to escape his unhappy marriage. His first trips in 1913-14 left him enchanted with the country and the people: back home in England on November 14, 1914, he began working on the translation of Russian folktales and also looking for a job to use the Russian experience he had acquired. Too near-sighted for military service in the army, he eventually took up a journalistic career with the Daily News and then with the Manchester Guardian to report on the dramatic Russian events up to 1924 (Brogan, 1984, pp. 95-110).

In Russia, Dmitri Isidorovich Mitrokhin (18831973) was to play a most important role in Ransome's intercultural environment. At first, Mitrokhin was a student at the Moscow College for Art, Sculpture and Architecture, then at the Stroganovsky College for Arts and Crafts. Evgeni Lansere lent a helping hand to the young artist, securing commissions from publishers and thus encouraging Mitrokhin in his career as a book and magazine illustrator. In 1908, Mitrokhin was invited to participate in the Mir Iskusstva (World of Art) exposition arranged by Alexander Benois and Konstantin Somov, the well-known artists and the founding members of the society. In 1910-13, Mitrokhin made his name as an illustrator of W. Hauff's Der Kleine Muck and V. A. Zhukovsky's Roland-oruzhenosets while working for I. N. Knebel, the publisher of popular illustrated children's books. Mitrokhin's works, with his "distinctly individual ornamental style" (Gerchuk, 2013, p. 246, 262) are recognized as exemplary of graphic arts in the illustrious pre-revolutionary Russia (Kniga o Mitrokhine, 1986).

Close reading of both primary and secondary sources, including the translated texts under study and related archival materials, such as personal correspondence, as well as exploring other papers pertaining to the translator's micro-history (Pym, 2009; Monday, 2014) have all been employed here as particularly relevant methods for translation history research.

The textual features of the translated stories have been analyzed in other publications (Bogrdanova, 2010, 
2010a, 2012) and will not be revisited here; instead, this paper focuses specifically on the interplay of text and image against the background of personal communication between the translator and the artist, as well as the wider context of British-Russian cultural interaction at the turn of the twentieth century.

Thus, the paper explores Ransome's agency as a translator by reconstructing the general intercultural atmosphere of the period, as well as focusing on his cooperation with the Russian artist Mitrokhin. The analysis of the textual and visual components of the translated texts indicates their complex interplay that helped to produce an interesting interpretation of the Russian folktale for international audiences. Resulting from Ransome's own immersion in the culture he was translating for the young English reader, his book is a major contribution to the internationalization of the Russian folktale, as well as to building an important link between the two cultures and countries.

\section{Results and Discussion}

Of the numerous and ever-growing literature on that most interesting period known as Russian modernism, or the Silver Age, one book with a characteristic title, The Soul of Russia, deserves special attention. It was compiled with the specific aim of celebrating and fostering the British-Russian alliance during the Great War, and it recalls the voices of the actors engaged in the contemporaneous cultural practices and interactions on both sides. Contributions by K. Balmont, V. Bryusov, Z. Gippius, etc., as well as illustrations after paintings by L. Bakst, N. Goncharova, M. Larionov, N. Roerich, D. S. Stelletsky, "portray the influences which direct, the ideals which inspire, and the ardent sentiments which impassion contemporary Russian thought" (The Soul of Russia, 1916, p. vi).

This cultural atmosphere was most conducive for an enthusiastic student of folklore like Ransome was at the time of his arrival in Russia, where visual artists, musicians, and choreographers took a different approach to folk art in revival movements and modernist compositions (Olson, 2004, p. 26). In painting, Vasilii Kandinskii, Natalia Goncharova, and others evolved new, abstract artistic techniques based on folk designs. The Ballets Russes produced many ballets "incorporating Slavic folk themes", while the artists "emphasized aspects of Russian art that were striking to Western audiences” (Olson, 2004, p. 27). In Nicholas Roerich's words, "By means of a recently awakened interest in contemporary Art, by the study of our past, we have realised what an original treasure we possess" (The Soul of Russia, 1916, p. 24).

At the same time, "Russian Art has received great recognition from our friends, our Allies in the West", according to Roerich who remembers his share in Dyagilev's dramatic representations "with a feeling of deep emotion" as "hands unknown, but sincerely friendly, were stretched out to us" (The Soul of Russia, 1916, pp. 2425). C. Hagberg Wright, on the British side, commented on the enthusiastic reception of Tolstoy, Dostoevsky, Gorky, who portrayed "the moujik with a sensitive and intimate touch" so that all "intellectual Europe was converted, and the seeds of international understanding were sown" (The Soul of Russia, 1916, p. 25, 15). The translation of the Russian literary canon into English, which was "arguably the major translation project of British modernism" revealed to English readers a body of imaginative work, "so new and exciting as to be shocking” (Beasley \& Bullock, 2011, p. 283; Trivedi, 2007, p. 277).

Interestingly, the 'Russian fever' of British intellectual circles seems to have been counterbalanced at this time by the 'Anglomania' of the Russian modernists, as convincingly stated by Ekaterina Vyazova (2009). At the end of the nineteenth century, the Russian public developed a passion for interior and furniture design, book and art magazines, as well as interest in English painting and graphic works (Vyazova, 2005, p. 284). The very image of England was, at times, shaped by English books and magazines. Alexander Benois (mentioned above) left compelling evidence of his first visit to England in 1899 where the countryside increasingly resembled "the classic English sets, against which lovely dressed girls strolled and romped or ardent hunters clad in red tails rode in children's books by Kate Greenaway and Caldecott" (as cited in Vyazova, 2005, p. 286).

Between 1897 and 1903, five major exhibitions were staged in Moscow and St Petersburg with a focus on English art; they were of special importance to the 1890s generation of artists who went on their first trips to Europe (Vyazova, 2005, p. 286), including Mitrokhin. The artistic traditions of the countries were revealing "surprising parallels", such as the similar technique of folk motif stylization used by Walter Crane, Maria Iakunchikova and Elena Polenova; a huge influence of Beardsley; and the similarity of some iconographic motifs. Boris Anrep noted that Russian works were admired precisely for those features that, at the turn of the century, Russian artists admired so much in English art, such as the "relation [...] between the artists and their original Russian culture; the Russians' ability to compose fantastic pictures; decorativeness; and deeply religious profession of art" (as cited in Vyazova, 2005, pp. 295-296). Also, while interest in Russia and Russians was "sharpened by a war that united the British, French and Russians in a military alliance", personal contacts were more actively engaged; these too contributed to the positive reception of Russian art in Europe (Kaznina, 2005, pp. 340-341).

Such were the cosmopolitan tendencies of the period that, when in pursuit for his passion for folklore, Ransome found himself again in St Petersburg (Petrograd) in 1915 to focus on his translation project. According to his personal papers from this time, he fully took advantage of a short pause when the deprivations of the war were 
not yet acutely felt and before journalistic duties took up all his time.

Steady progress is accurately recorded in the diaries, but there is more detail in the letters, when Ransome reports happily to his mother that he was "working away here, gradually getting together material for a rather charming book, very much improving my Russian, translating fairy stories and rewriting them" (Ransome, 1915, \#62, February 4). ${ }^{1}$ But then his health started to fail him; fortunately the Tyrkovs-Williamses, his close friends at the time, came to the rescue, inviting to pay a long visit to Vergezha on the river Volkhov: "We go down by a train leaving Petrograd at midnight, and at four in the morning get on board a little steamer and go up the river to the place where they live, a beautiful old house, judging from pictures I've seen on a promontory in the river itself" (Ransome, 1915).

It was here, in the midst of the Russian countryside, while immersed in the world he was recreating, that he finished his book that bears clear marks of happy experiences: "my life has been nothing but steady work, so many hours each day, with a little fishing either at sunset or before breakfast. This week again my total is fifty-three pages. [...] It's rather jolly, the stuff I've been doing here". The romantic side of the great lover of the rustic idyll is also revealed: "I would like to stay here forever, and live in a hut with the timbers criss-crossing at the corners, and sleep on the stove at night, and have a flat-bottomed boat for summer and a sledge for winter and a little pony with a ragged tail" (Ransome, 1915).

In the mid-summer of 1915, "the last of the fairy stories has gone off to Jack [his publisher]" when, to his great disappointment, he learned "that the Russian fairy stories won't be published till next year, 1916" (Ransome, 1915 , \#78, July 14). But there is good news too as "they have decided to let me have coloured illustrations to my Russian fairy tales and [...] I am to find an artist out there to do the job" (Brogan, 1997, p. 32).

Back in Petrograd while "working extremely hard for the Daily News", Ransome was going steadily on with his translations, "if only a sentence a day", seeing also his Russian friends and "particularly Dmitri Mitrokhin, who was just finishing the admirable series of pictures [...] for Old Peter's Russian Tales". The artist was recommended to him by Konstantin Somov (mentioned above), who he knew through Hugh Walpole, one of a closely-knit British community of journalists and authors that crowded Petrograd. The publisher being "very pleased with the Russian illustrations to the fairy stories", the whole lot of Mitrokhin's pictures and final corrections to Old Peter were sent safely home in the Embassy bag (Ransome, 1916, \#104, July 17; Ransome, 1976, p. 193).

Although many texts "allow" or "demand" new

Tatiana Bogrdanova's visits to study Ransome's archive of the Brotherton Collections (Leeds, UK) in 2014-15 and Mitrokhin's papers in RGALI (Moscow) in 2015 were possible thanks to Research Abroad Grants of the Philosophical faculty, University of Eastern Finland. illustrations from time to time, there are books that are inextricably related to the pictures of one artist (for example, John Tenniel's illustrations for Alice's Adventures in Wonderland), for there is a "symbiotically empathic relationship between the author and the illustrator" (Fischer, 2008, p. 98). This seems to be the case regarding Ransome and Mitrokhin, who developed an affinity both on a personal level and in terms of their joint work. Being of nearly the same age, they appear to have shared a number of interests, among these: Paris, which Ransome frequented as a London bohemian and where Mitrokhin became acquainted with Western art; British art and artists, with Mitrokhin's special interest in Walter Crane, one of whose books he translated; and, of course, Russia and the Russians. Importantly, they shared a common passion as both were keenly interested in books and everything related to books.

For his love of reading, Ransome pays tribute to his mother, "I do not think that there was anything in my childhood for which I have more reason to be grateful than my mother's regular reading aloud, and the habit of eager reading to myself that her reading encouraged"; in fact, books and authors he mentions show a wide range of reading interests (Ransome, 1976, p. 37, 43, 60). Notably, his only complaint from wartime Petrograd was that "I have no time for reading. I've never read so few folk stories a week since first I came to Russia. And that's one of the things I don't want to let slip" (Brogan, 1997, p. 33). Similarly, Mitrokhin's profound understanding of everything concerning books was noted by his fellow colleague in a review of the artist's early work (Voyinov, 1921, pp. 32-33)2. Books are a constant topic in the lifelong correspondence he maintained with his sister even in old age (Mitrokhin, RGALI, \#589), when he writes, for example, that he was "very-very happy" to have recently purchased a German book on Rembrandt, "a rare wonderful treat" he made himself (Mitrokhin, 1964, April 25).

Details of his work on Old Peter's illustrations are not sufficiently documented; however, there are some relevant references in Mitrokhin's notes of a more personal character (Mitrokhin, RGALI, \#573). For example, in a note from 1938 made in pencil, he mentions his acquaintance with Ransome in 1915 and his drawings. Also of interest is the artist's comment on his illustrations to French folktales, where he writes that he is quite interested in them, trying to realize in full all his understanding of a book illustration based on the text, adding and explicating it (Mitrokhin, 1958, May 3). The artist was delighted to learn that his sister had Knebel editions and Ransome's book, the latter, he notes, marked the end of his Knebel period (Mitrokhin, 1962, August 11).

A brief exchange of letters that followed in the 1960s after a long pause reveals the character of their relationship (Mitrokhin, RGALI, \#730). Notably, Mitrokhin addresses Ransome in Russian: "I am not sure of the address on the

Translations from Russian here and further in text are our own. 
envelope that I am using for absence of any other; but I do want to write to you and I do want my letter to reach you" (Mitrokhin, 1962, April 4). "Artur Kirillovich" was so delighted that he tries to answer in Russian, but then has to confess that after such a long interval, it is too difficult for him though he can "still read Russian quite freely" (his second wife Evgeniya Shelepina was Russian): "You can have no idea how delighted I was to have your letter. It brought back the happiest memories of Petrograd and of my great good fortune in finding the best of all possible illustrators for the Russian tales that gave me so much pleasure. That book of stories is still alive and has been often reprinted". He adds that ,"I have often wished to visit Russia again, but it is too late now. I am 78 and very crippled with arthritis", though he adds, "it would be very pleasant if I had a magic carpet and could fly to the other side of Europe and share a samovar with my old friends of forty years ago" (Ransome, 1962, May 8).

Thus, the British author never changed his high opinion of the Russian artist who greatly contributed to their success, even though later editions of the book were illustrated by other artists as well. Having grown up with beautifully illustrated Andrew Lang's Fairy Books, Ransome must have been aware of the importance of an artist's contributions to the art of children's books, while Old Peter was meant to be part of the stock. Furthermore, he fully realized that it would be quite challenging for the young reader at home to understand and appreciate the magic of a strange world, and so took great pains to rewrite and adapt his retellings, also adding some framework stories that focused on explaining the wider context of Russian life and the folklore tradition (Bogrdanova, 2010).

Under the circumstances, Mitrokhin's contribution was more than welcome. His miniature head-pieces "made in the Mir iskusstva best style" - including, for example, such images as a river bank and a boat, a townscape with sharp angular tops of terems, a house in the forest, a sleeping winter forest blanketed by snow - associate with the spatial aspect of the tales rendered in an arbitrary and a fragmentary way. These, as well as such visual elements of the peasant world such as bales of hay, a horseman, a peasant woman in the field, butterflies and lily-of-the valley flowers, which are the themes of the end-pieces, offer information about the cultural context, as well as contribute to the rustic poetics of the stories. In the art critic's opinion, they are closer to the sharply expressive style of British book illustrators of the period, recalling such masters as Robert Anning Bell, Arthur Rackham, and Charles Robinson (Verizhnikova, 2000, pp. 29-30). Thus, Mitrokhin's visual vignettes with their cosmopolitan leanings, were effectively adding to Ransome's cultural mediation between the two worlds.

Notably, Ransome's translation strategy in retelling Russian tales to home audiences was largely domesticating, in keeping with the tradition established by Lang, the folklorist and editor of colored fairy books targeted at children. The addressee factor determined
Lang's editing practice of transforming folklore material from all over the world into a specific genre of English children's literature (Bogrdanova, 2010a). Similarly, in his collection of stories "written far away in Russia, for English children", Ransome transforms the Russian folktale to appeal to his younger reader at home. First, he is obviously interested in the original folktales that are meant for the target audience (for example, "The Cat who Became the Head-Forester", "Who Lived in the Skull?", “The Little Daughter of the Snow", etc.). But more often, Ransome rewrites them from the child's perspective so that, for example, a legend about a dispute between two rivers turns into a story about an argument between a younger and elder sister (see Example 1); or the wickedness of a witch may be downplayed and downsized ("Prince Ivan, the Baby Witch, and the Little Sister of the Sun"; see Examples 2 and 3) when it is only a witch baby playing games (though of a sinister kind) with her brother and the Sun's little sister (hence the frequency of the adjective little in the texts). Some examples of re-writings are included below:

1) And the little Vazouza was jealous of the Volga. "You are big and noisy," she says to the Volga, "and terribly strong; but as for brains," says she, "why, I have more brains in a single ripple than you in all that lump of water. "Of course the Volga told her not to be so rude, and said that little rivers should know their place and not argue with the great (Ransome, 1916, pp. 321-22); "Волга с Вазузой долго спорили, кто из них умнее, сильнее и достойнее большего почета" (Vazuza i Volga, 1984, p. 112).

2) He left his horse at the edge of the garden, and crept up to the ruined palace and peeped through a hole. Inside, in the great hall, was sitting a huge baby girl, filling the whole hall. There was no room for her to move. She had knocked off the roof with a shake of her head. And she sat there in the ruined hall, sucking her thumb.

And while Prince Ivan was watching through the hole he heard her mutter to herself, -

"Eaten the father, eaten the mother,

And now to eat the little brother"

And she began shrinking, getting smaller and smaller every minute (Ransome, 1916, pp. 148-49); “Приезжает Иван-царевич домой. Сестра выбежала, встретила его, приголубила: Сядь, - говорит, - братец, поиграй на гуслях, а я пойду - обед приготовлю» (Ved'ma i Solntseva sestra, 1984, p. 111).

3) How the witch baby gnashed her iron teeth!

"Give him up!" she screams.

"I will not," says the Sun's little sister.

"See you here," says the witch baby, and she makes herself smaller and smaller and smaller, till she was just like a real little girl. "Let us be weighed in the great scales, and if I am heavier than Prince Ivan, I can take him; and if he is heavier than I am, I'll say no more about it."

The Sun's little sister laughed at the witch baby and teased her, and she hung the great scales out of the 
cloud castle so that they swung above the end of the world. (Ransome, 1916, p. 153); «Ведьма стала просить, чтоб ей выдали брата головою; Солнцева сестра ее не послушала и не выдала. Тогда говорит ведьма: Пусть Иван-царевич идет со мной на весы, кто кого перевесит! Если я перевешу - так я его съем, а если он перевесит - пусть меня убьет!» (Ved'ma i Solntseva sestra, 1984, p. 112).

As evidenced, the original story is often amplified as details are added either to explain or to make it more interesting and entertaining. Additionally, the events are rendered in a dramatic and emotional way with appropriate syntactic and lexical features of the texts producing the effect. Furthermore, the rhythm and musicality of the Russian tale, emphasized in the English retellings, becomes their prominent stylistic feature. The emotional dimension of the texts is aptly enhanced by the illustrations. For example, the bright primary colours and the decorative pattern of the dust jacket (Ill. 1) have a clear emotional appeal, creating the atmosphere of a joyous meeting with the reader, which is maintained by the coloured pictures. The frontispiece, also an illustration to a story The Fool of the World and the Flying Ship ("They sailed away once more over the blue sea") (Ransome, 1916, p. 70), beckons the reader to join the journey to the Russian fairyland in the company of seagulls, clouds, and fantastic waves. The boat of dark solid wood with rows of planks for a roof looks rather like a hut but a steady and strong one to be able to withstand storms and other dangers, the sails with picturesque patches notwithstanding (Ill. 2).

Importantly, there is a difference between the Russian texts in Lang's anthologies and Old Peter. In contrast to his predecessor, Ransome is careful to convey the distinctly individual character of the Russian tale (Bogrdanova, 2010a), which is further enhanced by Mitrokhin's effort to acquaint the foreign reader with the Russian peasant world and story. His coloured pictures interact with the text and, though they may refer to particular episodes of the stories and depict particular characters, the overall effect created by their colour, brilliance, and decorative details are emotionally powerful renderings of the beauty, magic, and elaborate style of the Russian fairy tale.

Mitrokhin's "admirable series of pictures" are imbued with a nostalgic appeal to the Silver Age, adding to the charm of the book. The most attractive of the full-page pictures is probably that of a poor step-daughter who was sent by her step-mother to the forest to die, but through the magic help of Frost (Morozko) himself, not only survives but is showered with riches for her sweet temper ("There she was, a good fur cloak about her shoulders and costly blankets round her feet") (Ransome, 1916, p. 64). There is beauty and peace in the picture that breathes perfect harmony: the goodness of a girl, not an otherworldly princess but a peasant girl attired in a colourful scarf and a warm fur jacket, sitting quietly on an ornately painted chest lost in her thoughts (no doubt about a happy life with a worthy husband). Her posture and mood echoed by those of a red breasted bird on a branch opposite, by immense fir trees in the foreground with branches heavy with snow counterbalanced by the snow-topped birch tree with its long delicate drooping branches and bright patches of red, yellow, mellow brown with touches of black enhancing and enlivening the white-blue-grey world of a pristine winter landscape (Ill. 3).

Thus, the overall purpose of the coloured full-page illustrations is to show the harmonious unity of nature and man, the Russian landscape and the peasant: elements of hyperbole or even grotesque are added to the otherwise quite typical and convincing images of the characters of the tales. Colour is used sparingly, as the artist's palette with bright red, golden yellow, green of the warmest shade, and almost transparent ultramarine contributes to the decorativeness of the illustrations (Verizhnikova, 2000, p. 31).

Interestingly, while exploring the intertextuality of Ransome's texts, Peter France finds parallels with the author's previous works, as well as with contemporaneous writing, such as a concern for detail (due to his study of Mabinogion) and "taste for the decorative" (deriving from his closeness to the Decadence and the Yellow Book) (France, 1995, pp. 34-35). But, more importantly, he notes that Ransome, the teller of Russian stories, is striving to make them "works of art" while the world he is evoking is in some ways "the exotic world" of Ballets Russes, of Russian painters or art books such as the Russian folktales illustrated by Bilibin (France, 1995, p. 44), though France does not comment on Mitrokhin's illustrations.

Through a close reading, one can easily see the affinity of the translator and the illustrator in their joint work that alludes to other texts and images and reflects current artistic norms, trends, and tastes. Importantly, the story of their friendship and collaboration is an interesting and significant episode, illustrative of the atmosphere of the British-Russian enchantment at the turn of the twentieth century.

\section{Conclusion}

In conclusion it may be emphasized that, firstly, the primary and the secondary sources carefully selected and analyzed above give convincing evidence of the characteristic developments in the British-Russian literary and artistic dialogues at the turn of the twentieth century, especially as reconstructed in the case study of the British translator's remarkable cooperation with the Russian artist. Secondly, their joint work is the product of a symbiotic empathy: the pictures emphasize, enhance, and expand the message of the texts, imparting to them the luster and radiance of the Russian Silver Age; moreover, the analysis of the interplay between the text and the picture shows the specific relevance of aesthetically and emotionally powerful images in rendering the culturally distinct character of folktales. Finally, the study of 
translators' micro-histories, with a focus on their agency embedded in the contemporaneous cultural practices, appears to be an effective instrument to make narrative sense of relations between cultures.

\section{References}

Beasley, R., \& Bullock, P. R. (2011). Introduction: Illusion of transparency. Translation and Literature, 20, 283300.

Bogrdanova, T. (2010). Russkaya skazka v angliyskoy traditsii perevoda [The Russian folktale in the English translation tradition]. Vestnik Moskovskogo Universiteta, 19(1), 103-113.

Bogrdanova, T. (2010a). Rol' Endryu Langa v transformatsii folklornoy skazki dlya detey [Andrew Lang's role in the transformation of folk tales for children]. Nauchnaya Misl' Kavkaza, 4(2), 70-76.

Bogrdanova, T. (2012). Russian folk tales for English readers: Two personalities and two strategies in the English translation of the late $19^{\text {th }}$ and early $20^{\text {th }}$ centuries. In A. Cross (Ed.), A people passing rude (pp. 113-124). Cambridge, UK: Open Book Publishers.

Brogan, H. (1984). The life of Arthur Ransome. London, UK: Jonathan Cape.

Brogan, H. (1997). Signalling from Mars: The letters of Arthur Ransome. London, UK: Cape.

Chaga, L. V. (Ed.). (1986). Kniga o Mitrokhine. Stat'i. Pis'ma. Vospominaniya [Book about Mitrokhin. Articles. Letters. Memoirs]. Leningrad, USSR: Khudozhnik RSFSR.

Fischer, M. B. (2008). Changes and exchanges: Variations in the illustrations in translated children's literature. In M. González Davies \& R. Oittinen (Eds.), Whose story? Translating the verbal and the visual in literature for young readers (pp. 97-111). Newcastle upon Tyne, UK: Cambridge Scholars Publishing.

France, P. (1995). From Russian tale to English children's story: The case of Arthur Ransome. New Comparison, 20, 30-45.

Gerchuk, Y. Y. (2013). Istoriya grafiki i iskusstva knigi [A history of graphics and book art]. Moscow, Russia: RIPHolding.

Kaznina, O. (2005). Boris Anrep: A Russian artist in an English interior. Journal of European Studies, 35(3), 339-364.

Kinnunen, T., \& Koskinen, K. (Eds.). (2010). Translators' agency. Tampere, Finland: Tampere University Press.

Mitrokhin, D. I. (1955). Letter of D. I. Mitrohin to M. V. Alpatov. In RGALI, f. 3094, op. 1, \#\#573, 589, 730.

Monday, J. (2014). Using primary sources to produce a microhistory of translation and translators: Theoretical and methodological concerns. The Translator, 20(1), 64-80.

Oittinen, R. (2005). Translating culture: Children's literature in translation. Literatuur Zonder Leeftijd, 19, 45-55.

Olson, L. J. (2004). Performing Russia: Folk revival and Russian identity. London, UK: Routledge.

Pym, A. (2009). Humanizing translation history. Hermes Journal of Language and Communication Studies, 42, 2348.

Ransome, A. (1916). Old Peter's Russian tales. London, UK: T. C. \& E. C. Jack.

Ransome, A. (1916). The project Gutenberg eBook of old Peter's Russian tales. New York, NY: Frederick A. Stokes.

Ransome, A. (1976). Autobiography. London, UK: Jonathan Cape.

Whale, W. S. (Ed.). (1916). The soul of Russia. London, UK: Macmillan.

Taruskin, R. (1986). From subject to style: Stravinsky and the painters. In J. P. Berkley \& L. Angelis (Eds.), Confronting Stravinsky, man, musician, and modernist (pp. 16-38). Berkeley, CA: University of California Press.

Ter-Minasova, S. G. (2000). Yazyk i mezhkulturnaya kommunikatsiya [Language and cross-cultural communication]. Moscow, Russia: Slovo.

Trivedi, H. (2007). Translating culture vs. Cultural translation. In P. St-Pierre \& P. C. Kar (Eds.), Translation - Reflections, refractions, transformations (pp. 277-287). Amsterdam, Netherlands: Benjamins.

Tymoczko, M. (1995). The metonymics of translating marginalized texts. Comparative Literature, 47(1), 1124.

Vazuza i Volga [Vazuza and Volga]. (1984). In E. V. Pomerantseva \& K. V. Chistov (Eds.), Narodniye Russkiye skazki A. N. Afanasyeva [Russian folktales by A. N. Afanasyev] (Vol. 1, p. 112). Moscow, USSR: Nauka.

Vedma i Solntseva sestra [The Witch and the Sun's sister]. (1984). In E. V. Pomerantseva \& K. V. Chistov (Eds.), Narodniye Russkiye skazki A.N. Afanasyeva [Russian folktales by A. N. Afanasyev] (Vol. 1, pp. 110-112). Moscow, USSR: Nauka.

Verizhnikova, T. F. (2000). Peterburgskiye britantsi. Iz istorii britanskoy kommuni v Sankt Peterburge: Arthur Ransome (1884-1967) [The British in St Petersburg. From a history of the British community in St Petersburg]. Yezhekvartalnik Russkoy Filologii i Kulturi, III(3), 7-33.

Voyinov, V. V. (1921). Knizhniye znaki D. I. Mitrokhina [Bookplates by D. I. Mitrokhin]. Petrograd, USSR: Izd. Petroplis.

Vyazova, E. (2005). Russia under 'the spell of anglomania' at the turn of the twentieth century. Journal of European Studies, 35(3), 283-297.

Vyazova, E. (2009). Gipnoz anglomanii: Angliya $i$ “angliyskoye" $v$ russkoy kulture XIX-XX vekov [Under the spell of anglomania: England and 'Englishness' in the Russian culture at the turn of the 20th c.]. Moscow, Russia: Novoye literaturnoye obozreniye. 


\section{Appendix A}

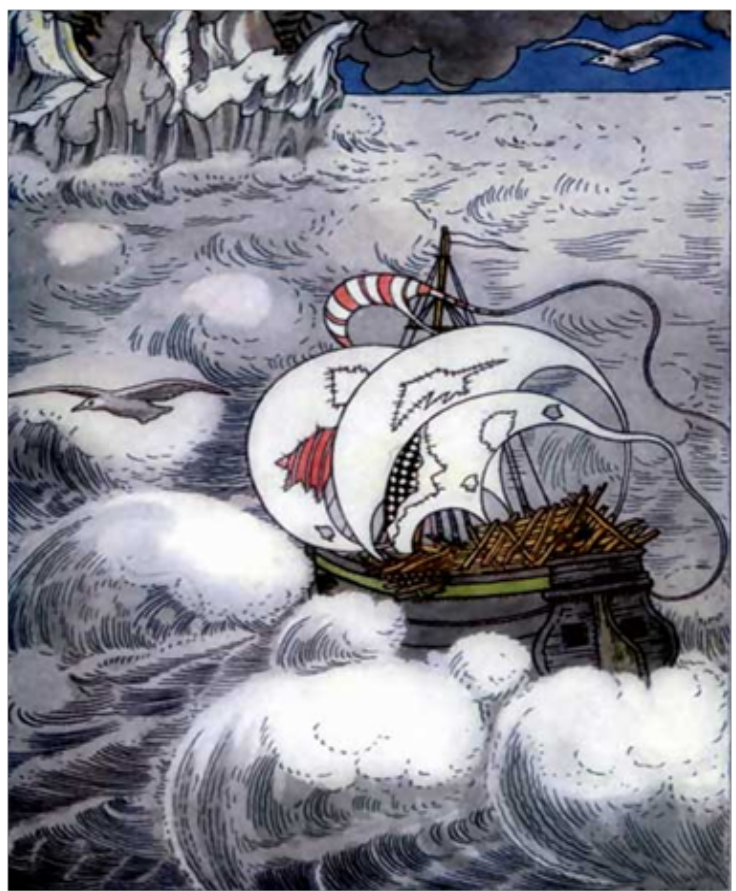

Illustration 1.

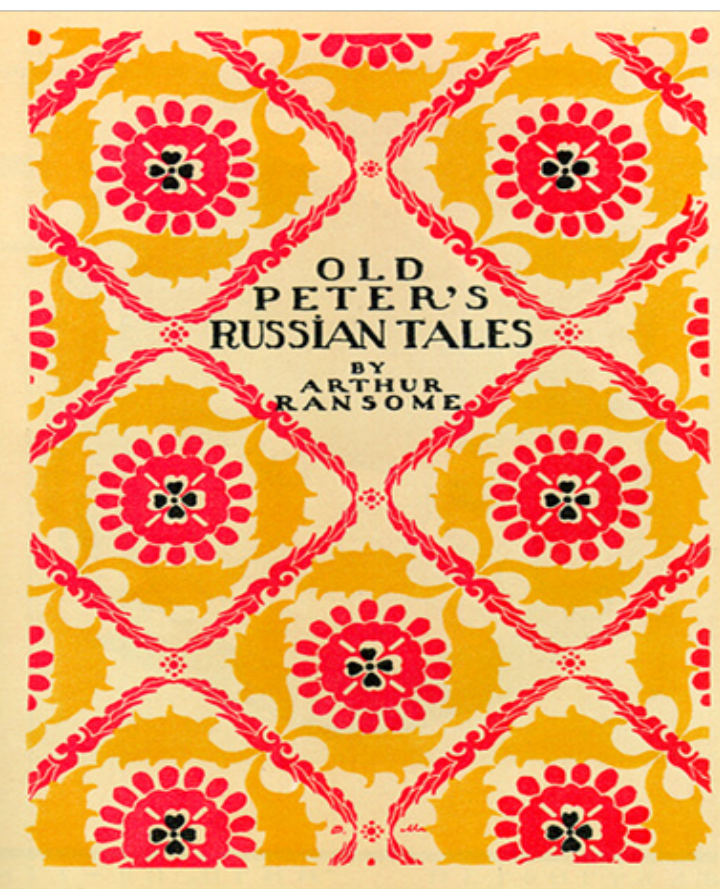

Illustration 2 .

Ransome, A. (1916). Old Peter's Russian Tales. ${ }^{3}$

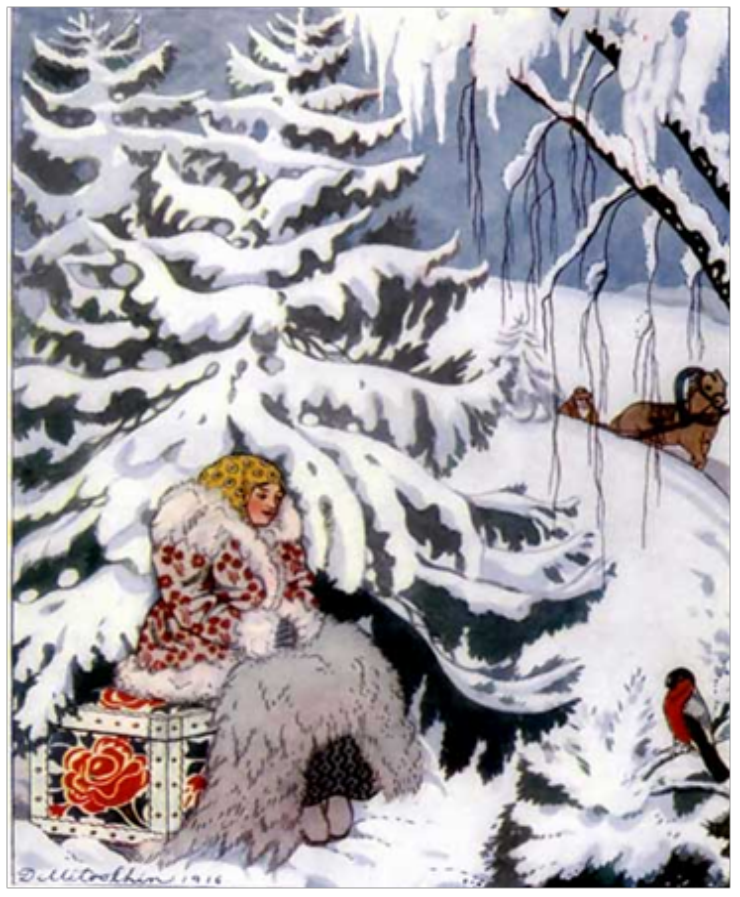

Illustration 3.

${ }^{3}$ Illustrations are taken from Wikipedia and The Project Gutenberg EBook of Old Peter's Russian Tales by Arthur Ransome (New York: Frederick A. Stokes Company Publishers, 1916). 